\title{
Debt crisis and 10-year sovereign yields in Ireland and in Portugal
}

\section{António Afonso \& Jorge Silva}

To cite this article: António Afonso \& Jorge Silva (2018) Debt crisis and 10-year sovereign yields in Ireland and in Portugal, Applied Economics Letters, 25:4, 217-222, DOI: 10.1080/13504851.2017.1310991

To link to this article: https://doi.org/10.1080/13504851.2017.1310991

册 Published online: 03 Apr 2017.

Submit your article to this journal

Џlll Article views: 235

View Crossmark data ¿ 


\title{
Debt crisis and 10-year sovereign yields in Ireland and in Portugal
}

\author{
António Afonso ${ }^{\mathrm{a}, \mathrm{b}}$ and Jorge Silva ${ }^{\mathrm{c}, \mathrm{d}}$ \\ aDepartment of Economics, ISEG/UL - Universidade de Lisboa, Lisbon, Portugal; bepartment of Economics, UECE - Research Unit on \\ Complexity and Economics, Lisbon, Portugal; 'Department of Economics, ISEG/UL - University of Lisbon, Lisbon, Portugal; ${ }^{\text {PPortuguese }}$ \\ Parliament, Parliamentary Technical Budget Support Unit, Lisbon, Portugal
}

ABSTRACT

We assess the determinants of the 10-year sovereign yield for the period 2000-2015, in Portugal and in Ireland. Results show that the long-term Portuguese sovereign yield increased with the rise of the 10-year Bund yield and during the Securities Markets Programme, but decreased due to financial integration. Additionally, during the period of the economic and financial adjustment programme, there was evidence of additional rises (decreases) due to increases (decreases) in the 3-month Euribor rate, and the level of public debt. EU/IMF funding reduced sovereign yield.

\section{KEYWORDS}

10-year sovereign yield; economic and financial adjustment programme; Portugal; Ireland

JEL CLASSIFICATION C20; E44; E62; G01

\section{Introduction}

As fall out from the 2009-2010 economic and financial crisis, Portugal and Ireland needed financial support to roll over public debt and they both adopted economic and financial adjustment programmes (EFAPs) ${ }^{1}$ in 2011 (European Commission, 2011a, 2011b). ${ }^{1}$ These euro area countries had external deficits and were more vulnerable to external shocks than those euro area countries that recorded external surpluses. In this article, we assess the determinants of 10-year sovereign yields in Portugal and in Ireland, notably in this context of crisis.

In the related literature, Lane (2012) argues that at the moment of the crisis, the euro area had a low degree of fiscal and banking union with identified risks of multiple equilibria when sovereign debt is high. This 'bad equilibrium' leads to the risk of selffulfilling speculative attacks, that is, an increase in perceptions of default risk induces investors to demand higher yields. Therefore, the rollover of public debt is more difficult and makes default more likely. On the other hand, the European Stability Mechanism and the ECB's programme to purchase sovereign bonds could attenuate such dire market conditions.

Altavilla, Giannone and Lenza (2014) studied the macroeconomic effects of the Outright Monetary Transaction (OMT) programme announced during the period of July-September 2012, focussing on four countries: France,
Germany, Italy and Spain. Regarding the 2-year government bond yields, the OMT announcements decreased the Italian and Spanish yields by about $200 \mathrm{bp}$, and left unchanged the bond yields of the same maturity in Germany and France. The reduction of 10-year government bond yields in Italy and Spain (about 100 bp) was smaller than the decrease in 2-year bond yields.

Garcia-de-Andoain et al. (2016) studied the effect of liquidity provision by the ECB on the overnight unsecured interbank markets for the period 2008-2014. They report evidence that the ECB acted as lender of last resort for the banking system. Furthermore, there were two effects of central bank liquidity: the replacement of the demand for liquidity in the interbank market (financial crisis 2008-2010), and an increase in the supply of liquidity in the interbank market in Greece, Italy and Spain (the debt crisis of 2011-2013).

With regards to the impact of the unconventional monetary policy on the private sector, Ferrando, Popov, and Udell (2015) studied the effects on small firms during the period of the debt crisis (2009Q1-2014Q1). The authors concluded that small firms in the stressed countries were more likely to be credit-rationed through price and quantity. However, there was evidence that the OMT decreased the share of credit-rationed firms.

\footnotetext{
${ }^{1}$ The economic and financial adjustment programmes were implemented in different periods: Ireland (2011-2013) and Portugal (2011-2014).

๑ 2017 Informa UK Limited, trading as Taylor \& Francis Group
} 
Andrade et al. (2016) analysed the effects of the expanded asset purchase programme (APP) on the economy, sovereign yields and transmission channels. The APP was announced in January 2015 and it decreased sovereign yields on long-term bonds, as well as increased the share prices of banks. The results are consistent with the portfolio rebalancing channel due to the removal of duration risk as well as the relaxation of leverage constraints for financial intermediaries.

Our results show that the Portuguese 10-year sovereign yield decreased due to the reduction of the 10-year Bund yield, as well as on account of the increase of financial integration in euro area government bonds. During the period under the Securities Markets Programme (SMP), there was a strong increase of sovereign yield. Throughout the EFAP, additional decreases (increases) of the 3month Euribor rate decreased (raised) 10-year sovereign yield. Furthermore, the Portuguese public debtto-GDP ratio had a nonlinear effect on the dependent variable. The EU/IMF funding also reduced the 10-year sovereign yield. The results for Ireland are less statistically significant.

\section{Methodology and data}

Equation (1) presents the dependent variable - the q-o-q variation of the 10-year sovereign yield, decomposed between external and domestic factors:

$$
\begin{aligned}
& \left(\text { yield }_{t}^{10 y e a r}-\text { yield }_{t-1}^{10 y e a r}\right) * 100 \\
& =\beta_{0}+\beta_{1} Z_{t}^{\text {external }}+\beta_{2} W_{t}^{\text {domestic }}+u_{t}
\end{aligned}
$$

where $Z_{t}^{\text {external }}$ is the set of external variables, and $W_{t}^{\text {domestic }}$ includes domestic variables.

During the period between the run-up to the introduction of the Euro and the financial crises, there was a reduction of the sovereign yield spread between Germany and the peripheral countries. Figure 1 presents a negative correlation between the main indicator for the cost of long-term funding and the indicator of financial integration (crossholdings of government debt). Furthermore, we can see how the implementation of the SMP by the ECB (May 2010-September 2012) led to a reduction of cross-holdings of government debt. Figure 2 details the public debt-to-GDP ratio and the 3-month Euribor rate. After the financial crisis, an accommodative monetary policy stance prevailed, although there was an increase in the public debt-to-GDP ratio. Also, at the start of the EFAP, there was an increase of the public debt ratio for Portugal and Ireland. The gap between the Portuguese 10-year sovereign yield and the 3-month Euribor rate was at its highest in 2012Q1 (1218 basis points), and lowest in 2007Q4 (-27 bp).

Figure 3 shows the value of total liabilities outstanding related to the loans from the international institutions since the EFAP. In Portugal, the EU/IMF funding-to-total public debt was higher than that of Ireland.

In line with economic theory, we included several domestic and external explanatory variables:

- Domestic factors: general government debt-toGDP, structural budget balance, potential output growth, inflation and dummy for the EFAP;
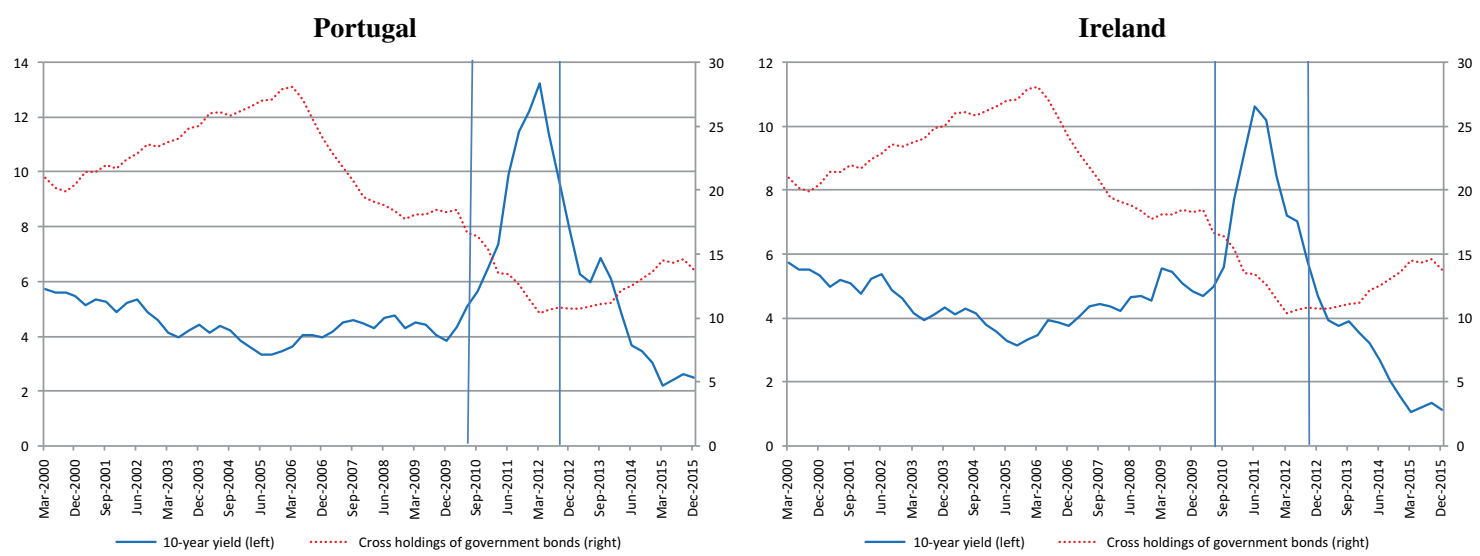

Figure 1. 10-year sovereign yield and financial integration indicator.

Sources: ECB and own calculations. The vertical lines denote the period of the SMP. 

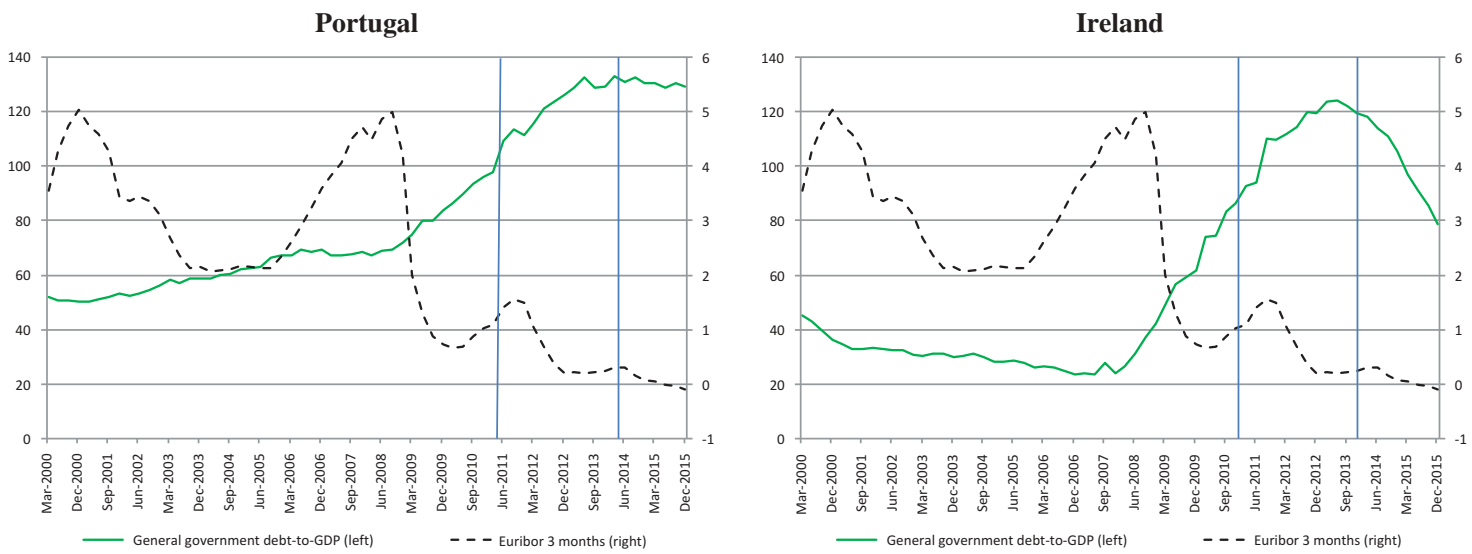

Figure 2. General government debt and 3-month Euribor rate.

Sources: Eurostat, ECB and own calculations. The vertical lines denote the period of the EFAP for Portugal and Ireland. There was a strong denominator effect in Ireland due to upward revisions of Irish GDP in 2015, related to the relocation of large companies.
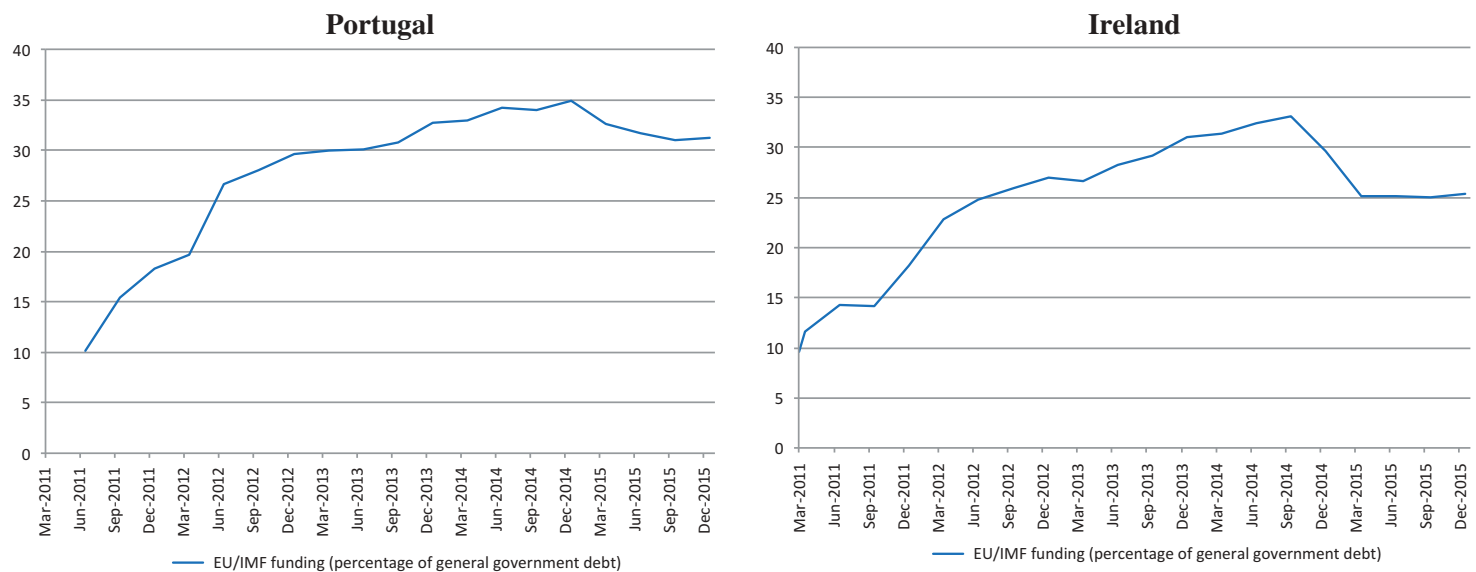

Figure 3. Loans from the EU/IMF funding.

Source: Portuguese Treasury and Debt Management Agency, National Treasury Management Agency, Eurostat and own calculations.

- Financial volatility: composite indicator of systemic stress (CISS) as measure of financial stress in Europe and VIX, and as a proxy for global financial volatility;

- Financial fragmentation/integration: the share of monetary and financial institutions cross-border holdings of euro area sovereign debt securities;

- Monetary policy: 3-month Euribor - the rate for the main refinancing operations and dummy related to the SMP;

- Control variables related to S\&P 500, dummy of the financial crisis since 2009 and the Bund yield as a benchmark of government bond yield for the euro area.

\section{Empirical analysis}

We estimate (1) in first differences in order to avoid nonstationary of some variables. Therefore, the q-o$\mathrm{q}$ variation of the 10 -year government bonds is the dependent variable. The following determinants are statistically significant in the case of Portugal (Table 1):

- Domestic factors: during the EFAP, the level of general government debt-to-GDP and the weight of the EU/IMF funding;

- External factors: the 10-year Bund yield, which is a benchmark for the costs of funding in the 


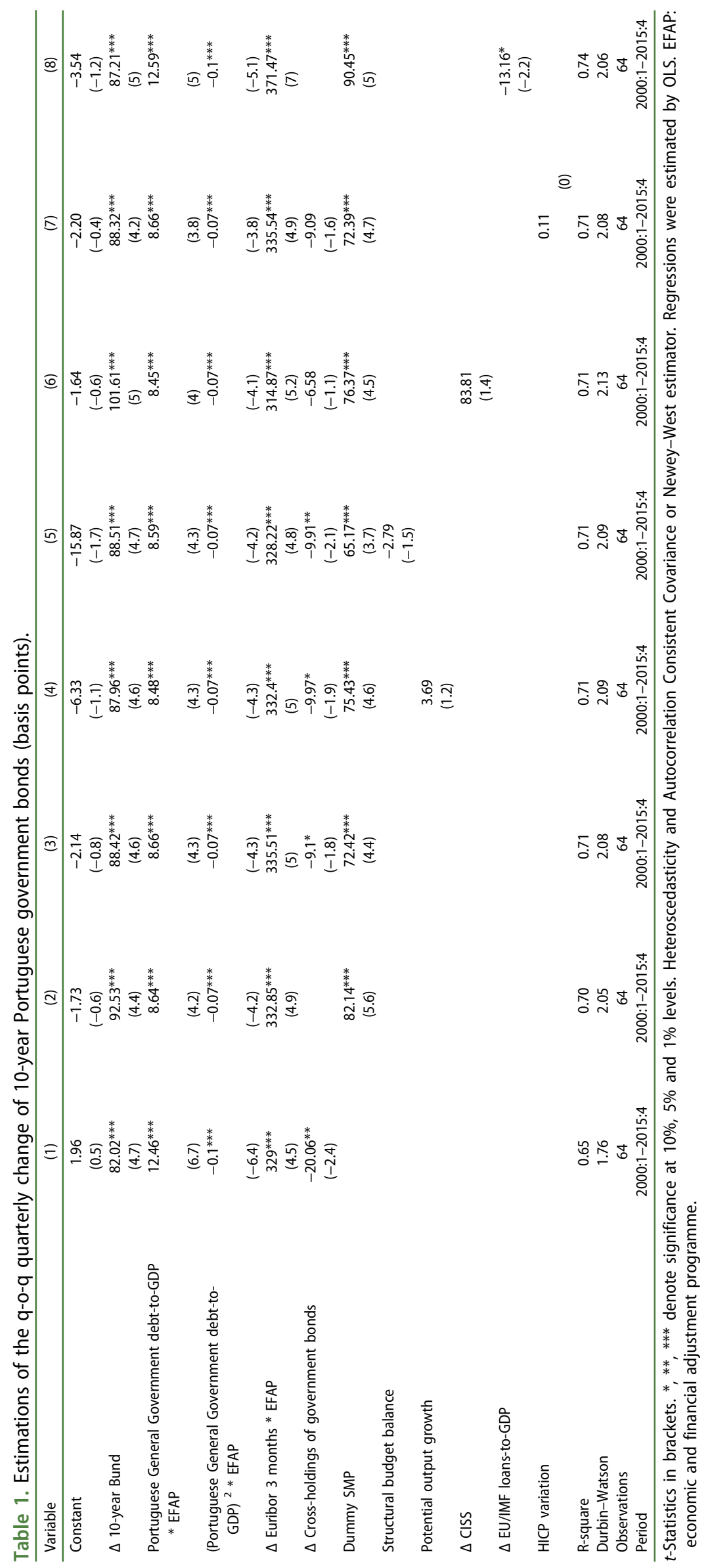




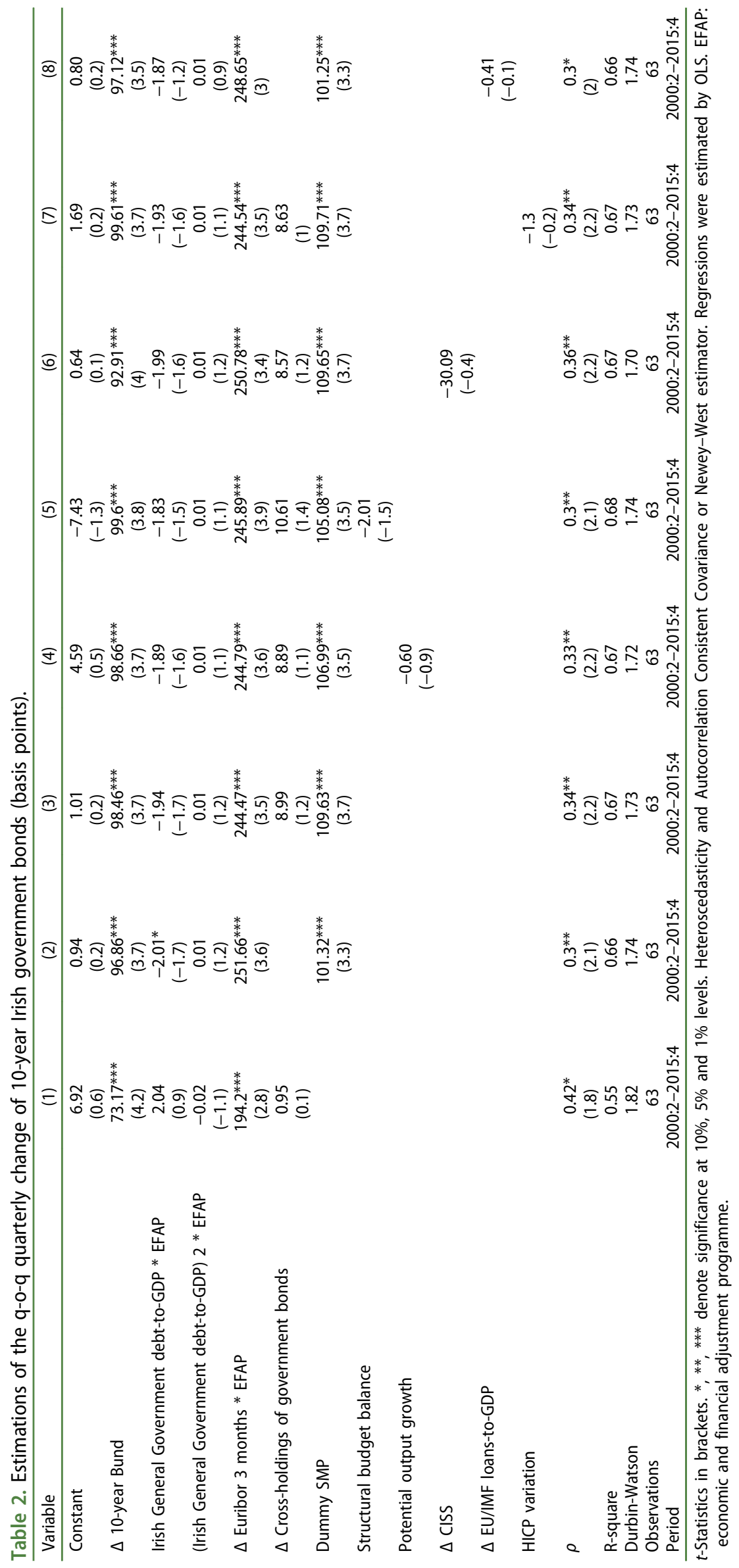


euro area and the financial integration/fragmentation of the euro area sovereign debt. During the EFAP, the 3-month Euribor.

Regarding regression (8) (Table 1), there was evidence that the Portuguese sovereign yield rose (87 bp) due to increases in the 10-year Bund yield (100 bp). During the SMP, the dependent variable increased (90 bp per quarter), in spite of the ECB's attempt to subdue the yield spike brought about by the sudden stop in capital flows. Throughout the EFAP, the level of debt ratio had a nonlinear impact on the sovereign yield. In fact, a public debt ratio of up to $126 \%$ increased the dependent variable. During the same period, a q-o-q variation of the 3-month Euribor (by $100 \mathrm{bp}$ ) increased the sovereign yield (by $371 \mathrm{bp}$ ). The EU/IMF funding, although marginally statistically significant, contributed to decrease the yield spread, and the effect also resulting from the cross-holdings of euro area sovereign debt.

For Ireland (Table 2), regression (5) shows that the $\mathrm{q}-\mathrm{o}-\mathrm{q}$ variation of the 10 -year sovereign yield was also explained by changes in the 10 -year Bund yield. $^{2}$ During the SMP, the dependent variable increased 105 bp per quarter. In addition, throughout the EFAP period, the variation of the 3-month Euribor (100 bp) increased the dependent variable (246 bp). Inflation, CISS, potential output, structural budget balance and financial integration had no statistical significance.

\section{Conclusions}

We studied the determinants of 10-year sovereign yields, focussing on domestic and external factors during the period 2000-2015. We assessed the Portuguese and Irish cases, which are two small open economies in the euro area, which had to implement economic adjustment programmes due to the European sovereign debt crisis.

Our results show that both the Portuguese and Irish 10-year government bond yields were determined by the q-o-q variation of the 10 -year Bund yield, as well as by financial integration. During the
SMP, the Portuguese sovereign yield rose, in spite of the ECB's purchases of government bonds.

Throughout the EFAP, the level of public debt-toGDP was a determinant for the increase of the sovereign yield for Portugal, and the 3-month Euribor, which is a proxy for monetary policy stance, was also a determinant for the variation of sovereign yields, both in Portugal and in Ireland. The existence of EU/IMF funding decreased the Portuguese 10year yield, but this was not the case for the Irish 10-year yield.

\section{Disclosure statement}

No potential conflict of interest was reported by the authors.

\section{Funding}

UECE is supported by Fundação para a Ciência e a Tecnologia (The Portuguese Foundation for Science and Technology).

\section{References}

Altavilla, C., D. Giannone, and M. Lenza. "The Financial and Macroeconomic Effects of OMT Announcements.” ECB Working Paper August 2014.

Andrade, P., Breckenfelder, J. H., De Fiore, F., Karadi, P., \& Tristani, O. "The ECB's Asset Purchase Programme: An Early Assessment.” ECB Working Paper September 2016.

European Commission. "The Economic Adjustment Programme for Ireland.” Occasional Papers 76 February 2011a.

European Commission. "The Economic Adjustment Programme for Portugal." Occasional Papers 79 June 2011b.

Ferrando, A., A. Popov, and G. F. Udell. "Sovereign Stress, Unconventional Monetary Policy, and SME Access to Finance.” ECB Working Paper June 2015.

Garcia-de-Andoain, C., Heider, F., Hoerova, M., \& Manganelli, S. "Lending-Of-Last-Resort Is as LendingOf-Last-Resort Does: Central Bank Liquidity Provision and Interbank Market Functioning in the Euro Area." ECB Working Paper February 2016.

Lane, P. R. 2012. “The European Sovereign Debt Crisis." Journal of Economic Perspectives 26: 49-68. doi:10.1257/ jep.26.3.49.

\footnotetext{
${ }^{2}$ The estimations for Ireland include a first-order autoregressive coefficient of the error term $(\rho)$ to solve autocorrelation problems.
} 